\title{
Foraminifera and
}

biostratigraphy of the Arnager Limestone, Bornholm, Denmark

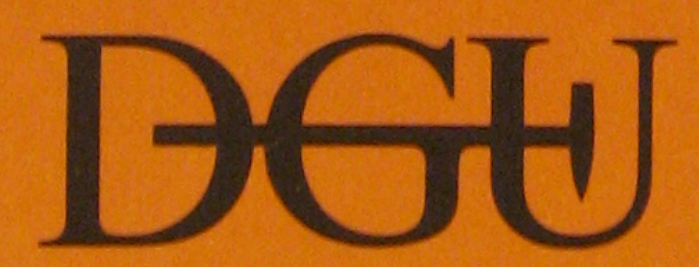

Geological Survey of Denmark

Ministry of the Environment

1986 


\section{Foraminifera and biostratigraphy of the Arnager Limestone, Bornholm, Denmark}

By Nikolaos Solakius and .

Kent Larsson

October 1985

DGU-serie C nr. 5

ISBN 8788640280

ISSN 09006362 


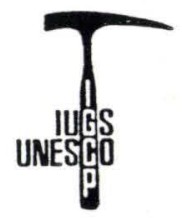

A contribution to PROJECT TORNQUIST

Vignette on front cover: Reussella kelleri

DGU serie, C nr. 5

ISBN : 87-88640-28-0

ISSN : 09006362

Printed in 750 copies

Print: DGU, offset

DGU 1985-12-20

Nicolaos Solakius and Kent Larsson, Dep. of Geology,

Historical Geology and Paleontology, University of Lund, Sölvegatan 13, S-223 62, Lund, Sweden

Editor: L. Banke Rasmussen

(C) Danmarks Geologiske Unders $\varnothing$ gelse

Thoravej 31, DK-2400 Kфbenhavn NV 
Abstract............................. 5

Introduction .......................... 7

Foraminiferal Biostratigraphy..................

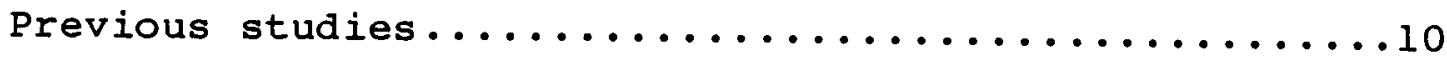

The present study..........................

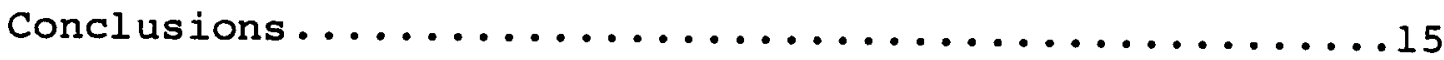

Systematic Descriptions.........................

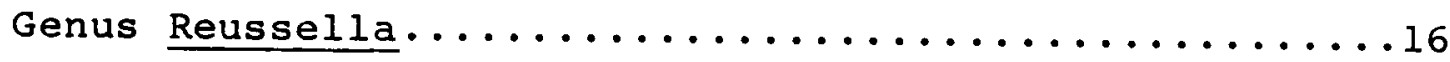

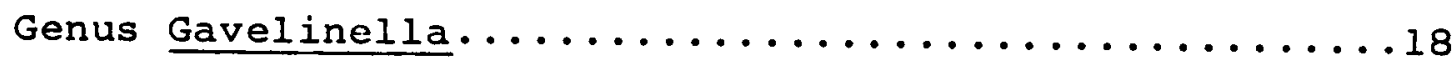

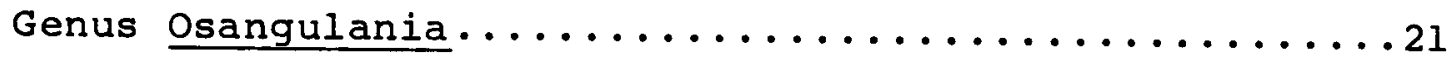

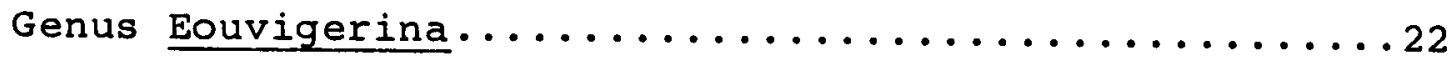

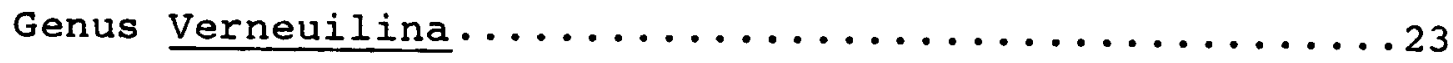

Genus Gaudryina............................ . . 24

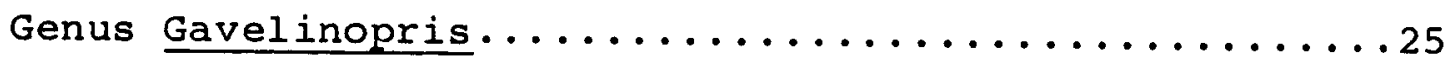

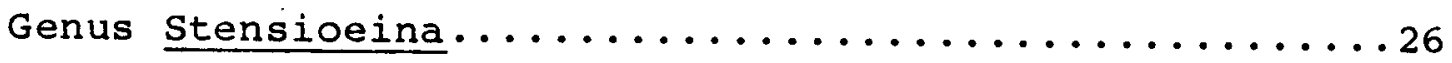

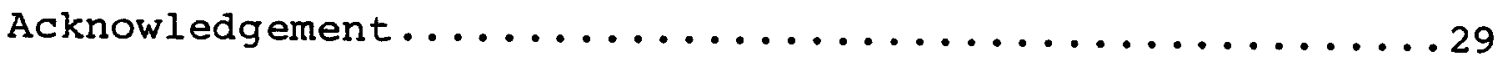

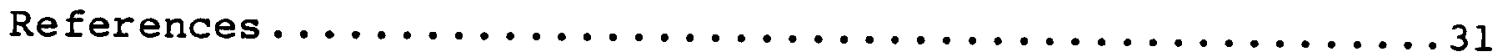

Plates................................... 
Foraminifera from the Arnager Limestone, Bornholm, have been recorded and identified. The fauna examined. indicated a Coniacian age for the Arnager Limestone. On the basis of this fauna two benthonic foraminiferal zones, the Reussalle kelleri Zone and the Stensioeina exsculpta Zone, are recognized in the limestone. Apart from the index species only the biostratigraphically most significant species are discussed. 
The three previous studies on the foraminiferal assemblages from the Arnager Limestone, Bornholm (Douglas \& Rankin, 1969; Stenestad, 1972; Bailey \& Hart, 1979)

have not dealt with the fauna in detail, nor has any attempt been made to distinguish any biostratigraphical zonation in this formation on the basis of Foraminifera although the fauna is well preserved.

Douglas \& Rankin (1969) only treated certain planktonic foraminiferal species from the upper part of the limestone, while Stenestad (1972) and Bailey \& Hart (1979) mentioned the occurrence of only a few planktonic and benthonic species. Their purpose was to provide valuable information for the determination of the enigmatic age of the formation.

In an attempt to distinguish the extent of the Turonian sedimentary beds in SW skåne and on Bornholm, and to establish a zonation on the basis of Foraminifera, we first examined the foraminiferal fauna from the Arnager Limestone (Figs. 1, 2) since there is much confusion regarding the age of this formation, some authors assigning it to the Turonian (e.g. Ravn, 1918, 1930; Brotzen, 1945; Birkelund, 1957) and others to the Coniacian (e.g. Christensen, 1973, 1983, 1984; Bailey \& Hart, 1979).

of the fauna investigated only the biostratigraphically useful species are presented here, those that provide important information about the time of the deposition of the Arnager Limestone and those that are zone markers. Thus, more attention was paid to determining the stratigraphical distribution of the species than to discussing their taxonomic status (Fig. 3 ). 
Except for the profiles showing the location of the samples collected (Fig. 2), the lithology of the Arnager Limestone is not discussed in this paper. A detailed lithological analysis of the limestone is in process and will be presented in a forthcoming paper.

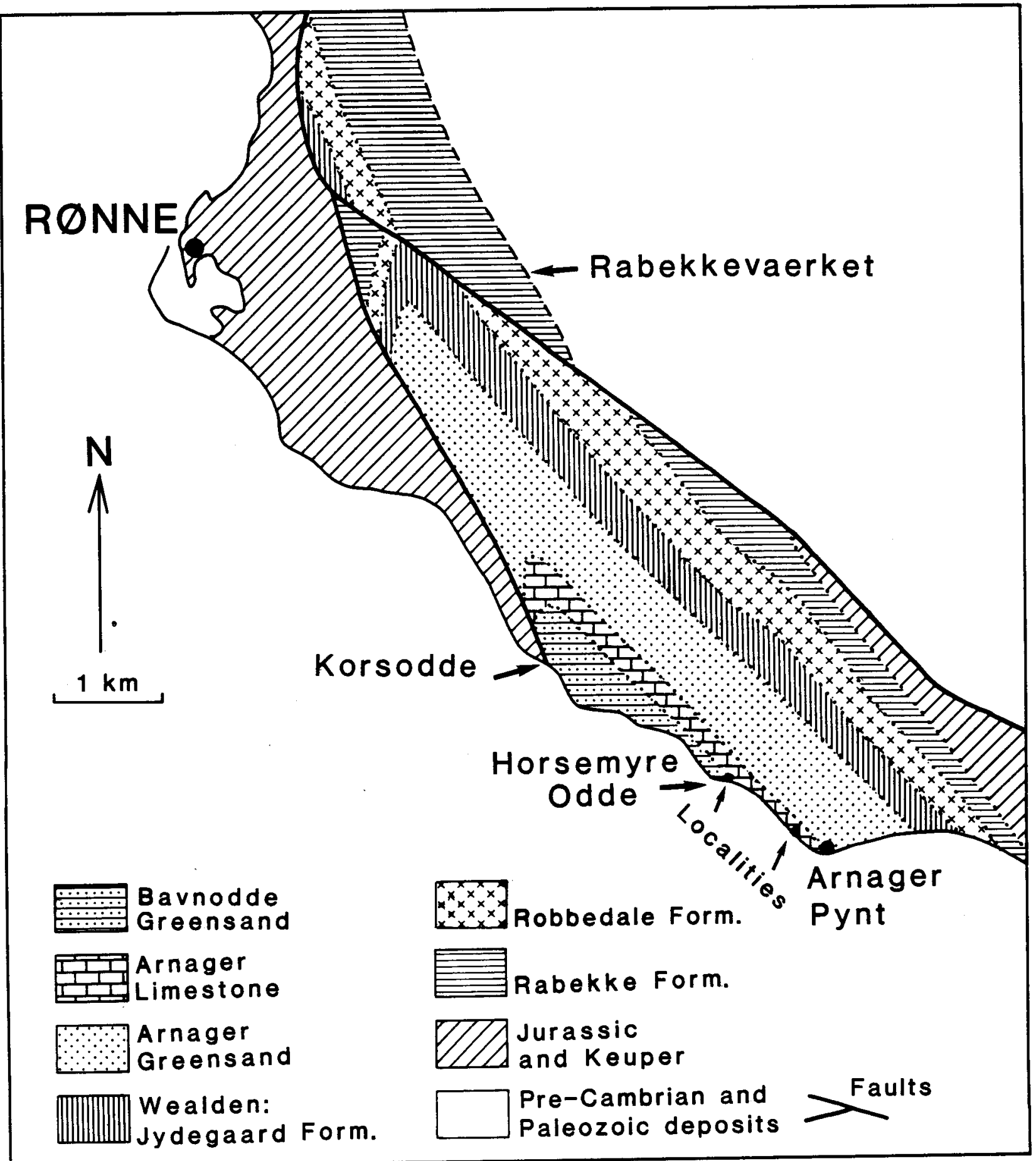

Fig. 1. Geological map of the southwestern area of the island of Bornholm showing the location of the sequences studied (map after Gry, 1960). 


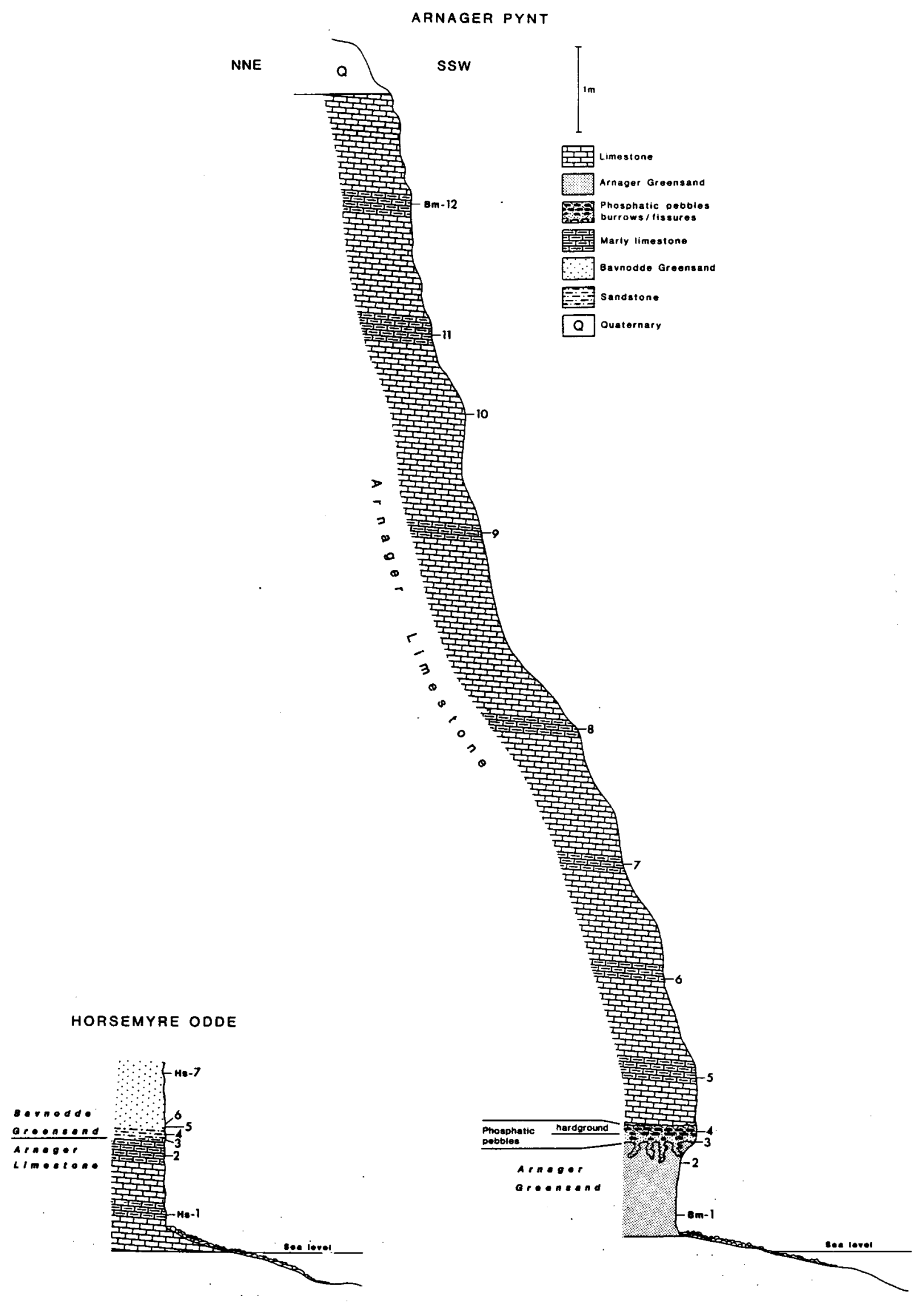

Fig. 2. Profiles of the Arnager Limestone at Arnager Pynt and Horsemyre Odde. 
Previous studies

Douglas \& Rankin (1969) examined certain planktonic Foraminifera from the upper third of the Arnager Limestone (only three samples were studied) and concluded that this formation possibly "spans from the Late Turonian to Coniacian and that "at least the upper part of the Limestone is Coniacian".

Stenestad (1972) also based his conslusions on the Foraminifera from these beds, agreeing with Douglas \& Rankin that the Arnager Limestone is of late Turonian - Coniacian age. He found that the fauna from the Arnager Limestone is dominated by such species that are considered characteristic of the Turonian but also of older or younger time intervals. However, additional species are found elsewhere in beds that are younger than the Turonian. Stenestad (1972) also agreed with Douglas \& Rankin that the molluscs recorded in these beds have been redeposited.

Bailey \& Hart (1979), who studied certain benthonic Foraminifera from the Arnager Limestone and the overlying Bavnodde Greensand, found that the limestone was of Coniacian age, and stated that certain species from the fauna recorded could be facies-controlled. They have also shown that there was a considerable hiatus, extending from the late Cenomanian to the earlier Coniacian, after which the Arnager Limestone was deposited.

The present study

The evidence of the foraminiferal analysis also indicates that the Arnager Limestone is of Coniacian age. The species 
Reussella kelleri Vasilenko,Verneuilina muensteri Reuss, Gavelinella thalmanni (Brotzen), Stensioeina exsculpta exsculpta (Reuss) and Osangularia whitei (Brotzen) which form part of the benthonic Foraminifera assemblage, appear in the Coniacian for the first time (Figs. 3, 4).

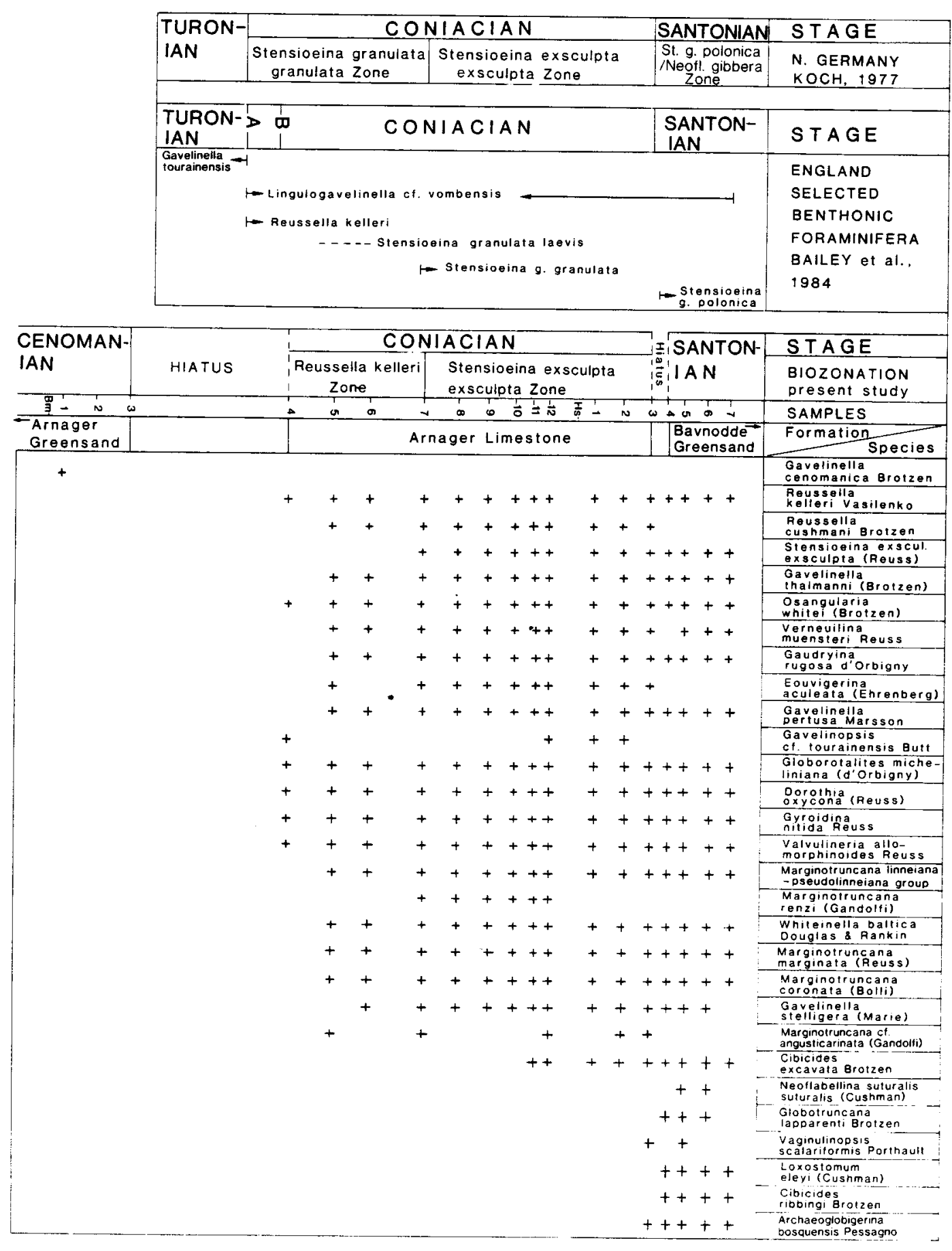

Fig. 3. Diagram showing (1) the foraminiferal zonation recognized in the Arnager Limestone and (2) the stratigraphical distribution of the species discussed. 
The presence of Gavelinella thalmanni, Gavelinella pertusa (Marsson) and Gaudryina rugosa d'Orbigny at the base of the sequence (cosmopolitan benthonic species which elsewhere are found in the upper part of the lower Coniacian for the first time, Fig. 4) indicates that the deposition of the limestone had at least begun in the later part of the earlier coniacian, as was also shown by Bailey \& Hart (1979).

\begin{tabular}{|c|c|c|c|c|c|}
\hline Species Stage & $\begin{array}{l}\text { TURO- } \\
\text { NIAN }\end{array}$ & CONIACIAN & SANTONIAN & CAMPANIAN & $\begin{array}{l}\text { MAASTRICH - } \\
\text { TIAN }\end{array}$ \\
\hline Gavelinella thalmanni & & & & & \\
\hline Reussella kelleri & & 1 & & + & \\
\hline Verneuilina muensteri & & 1 & & & \\
\hline Osangularia whitei & & & & $1++$ & \\
\hline Gaudryina rugosa & & $\longmapsto$ & & 1 & \\
\hline Gavelinella pertusa & & & & 1 & \\
\hline Eouvigerina aculeata & & & & 1 & \\
\hline Gavelinella stelligera & & $\begin{array}{l}1 \\
1\end{array}$ & & -+ & \\
\hline Stensioeina ex. exsculpta & & 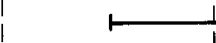 & & 7 & \\
\hline Gavelinopsis cf.tourainensis & & $-+H$ & & 1 & \\
\hline Marginotruncana cf. angusticarinata & & & & -1 & \\
\hline Globotruncana lapparenti & & 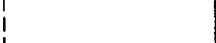 & & 1 & \\
\hline Neoflabellina s. suturalis & & $\begin{array}{l}1 \\
1\end{array}$ & & + & \\
\hline Vaginulinopsis scalariformis & & & & & \\
\hline Loxostomum eleyi & & $i$ & & $\frac{1}{1}$ & \\
\hline Cibicides ribbingi & & 1 & & & \\
\hline
\end{tabular}

Fig. 4. The total stratigraphical ranges of the most important species recorded in the Arnager Limestone and the Bavnodde Greensand.

The biostratigraphically important species Gavelinopsis cf. tourainensis Butt, sporadically recorded in the samples from the Arnager Pynt and frequently is $\mathrm{Hs}-1$ and $\mathrm{Hs}-2$ from Horsemyre Odde (Figs. 3, 4) indicates that the deposition of the Arnager Limestone did not extend into the Santonian. This species has previously been reported from the uppermost Turonian-Coniacian beds of France (Kuntz \& Monciardini, 1981; Robaszynski, 1983) and from the Coniacian of England (Carter \& Hart, 1977).

This contention is also supported by the fact that a Santonian foraminiferal assemblage occurs in the bed of the greensand resting on the limestone. The most important members of this assemblage are: (1) Globotruncana lapparenti 
Brotzen, a zone marker in the lower Santonian of the Upper Cretaceous in the valley of the River Vistula, Poland, marking the Globotruncana lapparenti Zone sensu Peryt (1980); (2) Neoflabellina suturalis suturalis (Cushman) (pl. 2, Figs. 21-23), another significant Santonian species which in association with Neoflabelina gibbera (Wedekind) and the Stensioeina granulata polonica Witwika, marks the Coniacian - Santonian boundary in the Upper Cretaceous beds of the Pompeckjsche Scholle (Koch, 1977); Vaginulinopsis scalariformis Porthault (pl. 3, Fig. 5), a benthonic species which is reported from the Santonian of France (Alpes/Maritimes) (Porthault, 1970) and England (Bailey \& Hart, 1979); (4) Loxostomum eleyi (Cushman) (pl. 3, Fig. 9) and Cibicides ribbingi Brotzen ( $\mathrm{pl}$. 3, Figs. 10-11), two cosmopolitan species which, according to Hart et al. (1981) made their first appearance in the latter part of the lower santonian.

It must be pointed out that the species Cibicides excavata Brotzen (pl. 1, Figs. 21-22), which in the Brezno Formation has been reported from the Santonian (Hercogova, 1983), is in our study found in the upper part of the limestone (Fig. 3).

The boundary between the Coniacian and Santonian was not found in our sequence because of an interruption in the sedimentation after the deposition of the Arnager Limestone. Evidence of this hiatus is the occurrence of Loxostomum eleyi and Cibicides ribbingi (which appeared in the later part of the lower Santonian) in the bed overlying the limestone.

The foraminiferal species presented form only part of the fauna recorded. The planktonic species described by Douglas \& Rankin (1969) from the upper part of the Arnager Limestone, are also found to be present in the lower part. In addition to those, however, other planktonic species are also found, the typical representatives of which are important for the biostratigraphy of the Coniacian in the Tethys and adjacent areas. These species, rare in our samples, are Marginotruncana cf. angusticartinata (Gandolfi) (pl. 3, 
Figs. 14-16) and some specimens which belong to Marginotruncana cf. paraconcavata Porthault (pl. 2, Figs. 11, 16-17) and Dicarinella cf. primitiva - Dicarinella cf. concavata group (pl. 1, Figs. 19, 23-24).

The benthonic species, on the other hand, have helped us not only to date the limestone but also to distinguish a foraminiferal zonation. The zones identified, the Reussella kelleri Zone and the Stensioeina exsculpta exsculpta Zone, are based on the ranges of the benthonic species Reussella kelleri Vasilenko and stensioeina exsculpta exsculpta (Reuss). Here it must be noted that the former species has recently been reported to mark in association with Lingulogavelinella cf. vombensis (Brotzen) the Turonian-Coniacian boundary in England (Bailey et al., 1984) and in Yonne, France (Pomerol, 1983).

The Reussella kelleri zone was originally established by Amedro et al. (1978) in the Upper Cretaceous sequences of the basin of Paris, marked by the first appearance of Reussella kelleri Vasilenko to the first appearance of Osangularia cordieriana ( $d^{\prime}$ Orbigny). According to them this zone represents the lowermost Coniacian (and possibly the top of the Turonian). It is distinguished in the lower part of the limestone, including the interval extending to the first appearance of stensioeina exsculpta exsculpta (Reuss) according to our definition.

The Stensioeina exsculpta exsculpta Zone sensu Koch (1977), originally established in the upper part of the Coniacian at Pompeckjsche Scholle, is present in the upper part of the Arnager Limestone (Fig. 3 ).

A more detailed description of these two Coniacian zones will be given when further and more complete Upper Cretaceous sequences, in which both boundaries of the Coniacian occur, are treated. According to the evidence of the Foraminifera examined rocks representing the lowermost Coniacian and the Coniacian-Santonian boundary, are lacking in the sequences discussed (Fig. 3 ). 
Conclusions

The above observations on Foraminifera from the Arnager Limestone and from the basal part of the Bavnodde Greensand point to the fact that the deposition of the limestone took place during the coniacian, bounded on both sides by a hiatus (Fig. 3). The second interruption, during the. beginning of the Santonian, did not last as long as the hiatus before the deposition of the limestone.

The foraminiferal assemblage examined has further helped us to distinguish a biostratigraphic subdivision in the $1 i-$ mestone. Two zones, the Reussella kelleri Zone, known from the lowermost Coniacian of the Paris Basin (Amedro et al.., 1978 ) and the Stensioeina exsculpta exsculpta Zone sensu Koch (1977) from the upper Coniacian of the Pompeckjsche Scholle, based on the ranges of the benthonic species Reussella kelleri Vasilenko and Stensioeina exsculpta exsculpta (Reuss), were distinguished.

Finally, it must be pointed out that no conclusions regarding the marine conditions under which the limestone was deposited, and the environment where the Foraminifera lived, have been drawn since the analysis of the lithology of the limestone is not yet complete. The discussion is, thereforp, limited to our attempts to determine the age of the limestone as well as to distinguish a biozonation on the basis of the Foraminifera examined. 
Genus Reussella Galloway, 1933

Type species: Verneuilina spinulosa Reuss, 1850

Reussella cushmani Brotzen, 1936

(pl. 1, Figs. 3,9)

1936

Reussella cushmani Brotzen: pp. 135-136, pl.8, Figs. 7a-c, text fig. 47.

1957

Reussella cushmani Brotzen; Hofker: pp. 205-207, text figs. 248-250

Remarks. - Reussella cushmani Brotzen, is distinguished by its triangular and triserial test; sides slightly convex and acute edges; chambers subtriangular in shape coiled in a number of whorls, increasing in size as added and overlapping each other. The last three chambers in some specimens are visible from the apertural view; apertural slit perpendicular to the inner margin of the last chamber and surrounded by a raised apertural lip.

As mentioned elsewhere this species is closely related to Reussella kelleri Vasilenko but differs from the latter in having acute edges and in lacking septal extensions or spines on its surface.

Occurrence. - Reussella cushmani was originally recorded by Brotzen (1936) in the lower Santonian Eriksdal marls in Skåne, Sweden. It has later been reported by Hofker (1957) from the Santonian - lower Campanian beds of northwestern Germany and Holland. Kuntz \& Monciardini (1981) found this species ranging from the upper part of the coniacian to lowermost Campanian beds in Normandy, France.

In the Arnager Limestone Reussella cushmani was originally 
recorded by Stenestad (1972). We found this species to occur throughout the limestone (Fig. 3).

Stratigraphical range. - Coniacian to lower Campanian. Material. - 17 specimens.

Reussella kelleri Vasilenko, 1961

(p1. 1, Figs. 1, 2)

1961

Reussella kelleri Vasilenko: pp. 176-178, pl. 38, Figs. 3-5, 12-13

1977

Reussella kelleri Vasilenko; Carter \& Hart: Fig. 3, no. 12

1981

Reussella kelleri Vasilenko; Hart et al.: pp. 216, pl. 7:22, Figs. 5, 6

Description. - Test medium sized, triangular, triserial with spinose surface in its earlier part. Sides slightly convex or flat; edges subacute. Chambers subtriangular in shape, increasing in size as added and overlapping each other. The last chamber is the largest and is furnished with an apertural slit which appears perpendicular to this chamber. This apertural slit is surrounded by a slightly raised lip.

Remarks. - Reussella kelleri is closely related to Reussella cushmani Brotzen, but differs from it in having spines or septal extensions in its earlier part and subacute edges.

Occurrence. - Reussella kelleri was originally recorded from the Coniacian and Santonian deposits of the Mangyshlak Peninsula, Kazakhstan, by Vasilenko (1961). Since then it has been reported by Monciardini (1978) from the TuronianConiacian boundary exposed at the northern part of the Paris Basin, from the Turonian-Coniacian beds at Cap Blanc-Nez, Calais, France, by Amedro et al. (1978), from the TuronianConiacian boundary at Beaumont-le-Roger (Normandy) by Kuntz \& Monciardini (1981), from the uppermost Turonian-Coniacian beds of France and adjacent areas by Robaszynski (1983), from the uppermost Turonian as $\underline{R}$. cf. kelleri Vasilenko, the Coniacian as typical R. kelleri of the Estessac Etpen-Other, 
France, by Pomerol \& Monciardini (1983), from the upper Turonian - Coniacian of the Brezno Formation, Bohemian, by Hercogova (1983), the Coniacian - Santonian deposits of England by Bailey (1978) and Bailey et al. (1984) and from the Turonian - Senonian boundary in the stratotype area at Sens (Yonne) by Pomerol et al. (1983).

In the Arnagar Limestone Reussella kelleri was first found to be present by Bailey \& Hart (1979) who also found it to range to the top of the overlying Bavnodde Greensand. In our samples from the Arnager Limestone this species occurs from the sample taken from the conglomeratic layer, throughout the limestone and to those samples taken from the base of the Bavnodde Greensand (Figs. 2, 3)..

Stratigraphical range. - The primitive form of this species called Reussella cf. kelleri is found to appear at the top of the Turonian. Its typical representatives on the other hand appear at the Turonian - Coniacian boundary and range to the lowermost Campanian (Fig. 4).

Material. - More than 70 specimens recorded.

Genus Gavelinella Brotzen, 1942

Type species: Discorbina pertusa Marsson, 1978

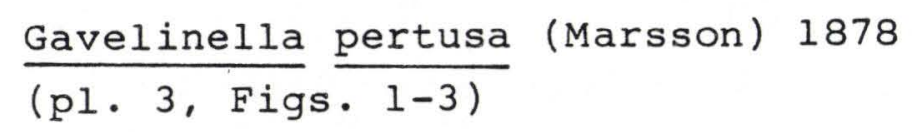

1878

1942

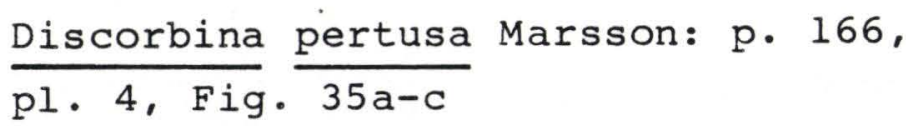

Gavelinella pertusa (Marsson); Brotzeu

1981 Gavelinella pertusa (Marsson); Edwards: pp. 41-43, pl. 1, Figs. 1, 2

1981

Gavelinella pertusa (Marsson); Hart

et al.: p. 196, pl. $7: 12$, Figs. 4-6

Remarks. - Gavelinella pertusa (Marsson) is characterized by its large, low trochospiral test which is coiled in a number of whorls; spiral side more convex than the umbilical side; 8-12 chambers in the final whorl which increase gradually in 
size in the direction of coiling; aperture an arcuate slit occurring on the umbilical peripheral part of the final chamber; umbilicus wide and open; surface with septal ridges which are not always well defined.

Occurrence. - Gavelinella pertusa was originally reported by Marsson (1878) in the Cretaceous of the island of Rugen, Germany. Brotzen (1942) when describing this species, has used specimens from the type locality (from the B. mucronata Zone) as well as from the Upper Cretaceous of Hollviken. Edwards (1981) recorded Gavelinella pertusa in the Upper Cretaceous sequences (from the $M_{\text {. }}$ coranguinum Zone to the $B$. mucronata Zone) of eastern England and northern France, and Hart et al. (1981) found it in the Upper Chalk, Norfolk, England.

In the sequence studied this species is found in all the samples collected from the Arnager Limestone and the Bavnodde Greensand (Fig. 3).

Stratigraphical range. - Coniacian - Maastrichtian.

Material. - 30 specimens.

1941

Gavelinella stelligera (Marie), 1941 (pl. 1, Figs. 6-8)

Planulina stelligera Marie; p. 245 ,

pl. 37, Figs. 344a-c

1981

Gavelinella stelligera (Marie);

Edwards: p. 404, pl. 58, Figs. 12-14

1981

Gavelinella stelligera (Marie); Hart

et al.: p. 196, pl. 7:12, Figs. 10-12

Remarks. - Gavelinnela stelligera (Marie) is distinguished by its almost circular and strongly compressed test; a large number of chambers occur in the last whorl where their septae form gently raised spiral ridges; on the umbilical side the test shows stellate arrangement of plates around the umbo.

Stratigraphical range. - Coniacian to lower Campanian. Material. - 22 specimens. 
Gavelinella thalmanni (Brotzen), 1936

(pl. 1, Figs. 11-13; pl. 2, Fig. 3)

1936

Cibicides thalmanni Brotzen: pp. 190-191, pl. 14, Figs. 7a-c

1956

Anomalina (Gavelinella) scuptilis Hiltermann \& Koch: p. 38, pl.$\overline{3, ~ F i g . ~} 3$

1977

Gavelinella thalmanni (Brotzen); Koch: p.41, pl. 48, Figs. 1-3

1981

Gavelinella thalmanni (Brotzen); Edwards:

p. 404, pl. 58, Figs. 7-11

1981

Gavelinella thalmanni (Brotzen); Hart

et al.: p. 198, pl. 7:13, Figs. 1-3

1982

Gavelinella thalmanni (Brotzen); Chatziemmanouil: Fig. $2 a-b$

Remarks. - Gavelinella thalmanni (Brotzen) is distinguished by its small, planispiral test; spiral side deep and furnished with an umbilicus; umbilical side flat composed only of the chambers of the last whorl; the chambers of this last whorl possess raised, well developed septal ridges on the spiral side which become thickened in the last two chambers: umbilical side smooth; periphery broadly with an aperture having an apertural lip.

Gavelinella thalmanni differs from other Gavelinella species in being smaller and in having an umbilicus on the spiral side. According to Edwards (1981) this species is evolved from Gavelinella schloebachi (Reuss) in the upper part of the lower Coniacian.

Occurrence. - Gavelinella thalmanni was originally recorded by Brotzen (1936) from the lower Santonian Eriksdal marls of Skåne, southern Sweden. Hiltermann \& Koch (1956) found this species in the Santonian beds at Lengende-Broistedt, West Germany, and Devriers et al. (1974) from the Coniacian of NE France. Later Koch (1977) reported it from the Coniacian lowermost Campanian of the Pompeckjsche Scholle, and Bailey (1978) found it in the Coniacian - Santonian beds of southern England. In the Senonian stratotype at Sens Pomerol et al. (1983) found Gavelinella thalmanni to range from the 
upper part of the lower Coniacian to the top of this stage.

In Sweden Gavelinella thalmanni was recently recorded by Norling (1978) in the Coniacian of the Kristianstad area (Harlov boring) and Chatziemmanouil (1982) found it in the Coniacian and Santonian beds of the Vomb Through.

In the sequence studied Gavelinella thalmanni appears from the base of the Arnager Limestone, ranges throughout it and continues upwards to the overlying Bavnodde Greensand (Fig. $3)$.

Stratigraphical range. - Coniacian to the top of the santonian.

Material. - 42 specimens.

Genus Osangularia Brotzen, 1940

Type species: Osangularia lens Brotzen, 1936

Osangularia whitei (Brotzen), 1936

(pl. 3, Figs. 17-19)

1936

Eponides whitei Brotzen: pp. 167-169,

pl. 12, Figs. 5-8, a-c

1981

Osangularia whitei (Brotzen); Hart

et al.: p. 212, pl. 7:20, Figs. 9, 10

Remarks. - Osangularia whitei (Brotzen) is characterized by its medium-sized and strongly biconvex test which is coiled in a number of whorls; spiral side strongly convex, umbilical side convex, periphery acute and keeled; last whorl composed of 7-8 chambers; sutures straight or slightly oblique; apertural slit on the umbilical side of the test furnished with a lip.

The species shows certain morphological similarities to Osangularia cordieriana (d'orbigny) but differs from the latter in being larger, in having a more convex umbilical 
side and in possessing a horizontal periphery compared with the sigmoid periphery of 0 . cordieriana.

To be sure that the specimens of Osangularia whitei from the Arnager Limestone are not misidentified, they were compared with the type material of this species as described by Brotzen (1936) (two paratypes of which are illustrated below) and found to be identical.

Occurrence. - Osangularia whitei (Brotzen) was originally described by Brotzen (1936) from the Eriksdal marls of skanne (lower Santonian). Since then it has been reported by Carter \& Hart (1977) from the Coniacian of the Thames Barrier, London, and from the Coniacian and Santonian of SE England by Bailey (1978). Hart et al. (1981) reported the range of o. whitei in England to be from the Coniacian to the lowermost Campanian.

In the Arnager Limestone this species was first found by Bailey \& Hart (1979). Osangularia whitei was found in all the samples collected from the Arnager Limestone and the Bavnodde Greensand (F.ig. 3 ).

Stratigraphical range. - Coniacian to lower Campanian. Material. - 80 specimens.

Genus Eouvigerina Cushman, 1926

Type species: Eouvigerina americana Cushman, 1926

$$
\frac{\text { Eouvigerina }}{\text { (pl. 3, Fig. 13) }}
$$

1854 Loxostomum aculeatum Ehrenberg: p. 22, pl. 27, Figs. 21-22

1926

Eouvigerina americana Cushman: p. 4, pl. 1, Figs. la-c

Eouvigerina americana Cushman; Brotzen: pp. 123-124, pl. 9, Figs. 4a-c

Eouvigerina americana Cushman; Montanaro-Gallitelli: p. 148, pl. 34, Figs. 1-5. 
1970

Eouvigerina aculeata Porthault: p. 57 , pl. 8, Fig. 25 .

1981

Eouvigerina aculeata (Ehrenberg); Hart et al.: p. 188, pl. 7:8, Figs. 3, 4

Remarks. - A species with a biserial, small free test having the last chamber in central position. Shape of the chambers reniform; chambers arrangement longitudinal to the opposite side of the proloculus; terminal aperture with well developed neck and lip.

Occurrence. - As emphasized by Hart et al. (1981) the stratigraphic value of this species has been devaluated because it has been described by numerous authors as Eouvigerina americana Cushman, Eouvigerina cretacea (Heron - Allen and Earland) and Eouvigerina serrata (Cushman). However, the records to date indicate the first appearance of $\underline{E}$. aculeata to be in the Coniacian. Hart et al. (1981) reported its range to be the lower Maastrichtian. In the Arnager Limestone this species is found to occur from the base of the limestone to its top (Fig. 3).

Stratigraphical range. - Coniacian to the lower Maastrichtian.

Material: -27 specimens.

Genus Verneuilina d'orbigny, 1840

Type species: Verneuilina tricarinata d'orbigny, 1840

Verneuilina muensteri Reuss, 1854

(pl. 2, Fig. 24)

1854

Verneuilina muensteri Reuss: p. 71 , pl. 26, Figs. 5a-c.

1960 Verneuilina muensteri Reuss; Tollmann: pp. 156-157, pl. 9, Figs. 7-8

1981 Verneuilina muensteri Reuss; Hart et al.: p. 178, pl. 7:3, Figs. 7-8 
Remarks. - Vernuilina muensteri Reuss possesses a large, triangular, triserial test, the chambers of which increase in size as added. The sides are slightly concave and the sutures are curved and slightly raised. The apertural opening is towards the centre of the inner margin viewed from the side.

Occurrence. - This spceies was described by Reuss (1854) from the Coniacian of the Edelbachgraben at Gosau. Later, Tollmann (1960) described it from the upper Coniacian of Gosau. Bailey (1978) found this species ranging from the base of the coniacian to the top of the Santonian of $\mathrm{SE}$ England. Hart et al. (1981) distinguished this species in the Upper Chalk, Santonian, of England and stated that the species ranged from the Coniacian to the lower Maastrichtian.

In the sequence examined, Verneuilina muensteri occurs throughout the Arnager Limestone and continues upwards to the Bavnodde Greensand.

Stratigraphical range. - Coniacian to the lower Maastrichtian.

Material. - 28 specimens.

Genus Gaudryina d'orbigny, 1840

Type species: Gaudryina rugosa d'orbigny, 1840

1840

Gaudryina rugosa d'orbigny, 1840

(pl. 3, Figs. 4, 8)

Gaudryina rugosa d'orbigny: p. 44 , pl. 4, Figs. 20, 21

1941

Gaudryina rugosa d'orbigny; Marie:

1946

p. 65, pl. 2, Figs. 33-23

1946

Gaudryina rugosa d'orbigny; Cushman:

1953

p. 32

1957

Gaudryina rugosa d'orbigny; Hagn: p. 14 , pl. 1, Fig. 14

Gaudryina rugosa d'orbigny; Hofker:

p. 63 , text-figs. 56,60 
Remarks. - A Gaudryina with a large and elongated test; the earlier part of the test is smaller and triserial in shape while the later part is biserially arranged having a quadrangular shape and is larger; sides flat, acute angles in the earlier part of the test, somewhat rounded in the later part; chambers fairly distinct; aperture crescentic in shape.

Occurrence. - Records of the occurrence of this species in the last 30 years have shown that it first appears in the Coniacian and ranges to the lower Maastrichtian (e.g. Cushman, 1946; Tollmann, 1960; Hagn, 1957, Hercogova, 1977). In the Arnager Limestone this species ranges throughout the limestone and continues into the Bavnodde Greensand.

Stratigraphical range. - Upper lower Coniacian to the lower Maastrichtian.

Material. - 50 specimens.

Genus Gavelinonopsis Hofker, 1951

Type species: Discorbina praegeri Heron-Allen \& Earland, 1913

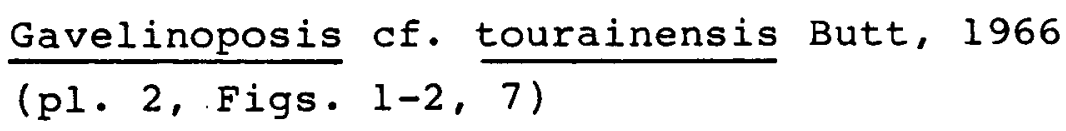

1977

Gavelinella cf. tourainensis (Butt);

Carter \& Hart: Figs. $3: 9$

Remarks. - This species is distinguished by its convex spiral side and flat umbilical side; it possesses a central raised boss on the spiral side of the test; the chembers are crescentic to subquadrate in shape.

This species is very similar to Gavelinopsis tourainensis 
Butt but differs from the latter in being flat on the umbilical side and much more convex on the spiral side of the test.

Occurrence. - Gavelinopsis cf. tourainensis is believed to be restricted to the uppermost Turonian and Coniacian stages. This is because it has only been reported from the uppermost Turonian of France and adjacent areas (Robaszynski, 1983) from the Coniacian of the Thames Barrier, England, (Carter \& Hart, 1977) and from the Coniacian of Normandy (Kuntz \& Monciardini, 1981).

In the Arnager Limestone this species occurs sporadically in the samples from the Arnager Pynt and is common in the samples from Horsemyre Odde (Fig. 2 ).

Stratigraphical range. - Uppermost Turonian to Coniacian. Material. - 10 specimens.

Genus Stensioeina Brotzen, 1936

Type species: Rotalia exsculpta Reuss, 1860

$\frac{\text { Stensioeina }}{1860}$ exsculpta exsculpta (Reuss).

(pl. 1, Figs. 16-18; pl. 2, Figs. 8-10)

1860 Rotalia exsculpta Reuss: p. 22, pl. 11, Figs. a-c

1936 Stensioeina exsculpta (Reuss); Brotzen: pp. 165-167, pl. 11, Fig. 8a-c

1968

Stensioeina exsculpta exsculpta (Reuss);

Trumper: pp. 21-25, pl. 8, Figs. 1-4a-c

1977

Stensioeina exsculpta exsculpta (Reuss);

Koch: pp. 40-41, pl. 11, Figs. 9-11

1981

Stensioeina exsculpta exsculpta (Reuss);

Hart et al.: p. 218, pl. 7:23, Figs.11-13

Remarks. - This subspecies is characterized by its planoconvex to slithtly biconvex test which is coiled in $3-31 / 2$ whorls; spiral side flat or slightly convex, ornamented, 
umbilical side convex; equatorial periphery sharply angled; chambers subrectangular; sutures raised and slightly curved on the spiral side, slightly curved and depressed on the umbilical side; umbilicus furnished with lips which almost overlap each other forming the shape of a star; aperture placed on the umbilical side of the last chamber.

Stensioeina exsculpta exsculpta was discussed in detail by Trumper (1968) who also presented a synonymy list. Koch (1977) used the restricted range of this subspecies to establish the stensioeina exsculpta exsculpta zone in the Coniacian of the Pompeckjsche Scholle, West Germany.

In the Arnager Limestone this subspecies occurs in the upper part of the limestone marking the stensioeina exsculpta exsculpta Zone and it continues upwards to the Santonian Bavnodde Greensand.

Stratigraphical range. - Upper Coniacian to the top of the Santonian.

Material. - 10 specimens. 
N. Solakius wishes to thank Dr. Christian Monciardini, Bureau de Recherches Geologiques et Minieres, France, for providing specimens of Reussella kelleri from the basin of Paris, and Prof. Peter Marks, Rijksuniversiteit, Utrecht, for sending part of the type sample of Gavelinopsis tourainensis. To complete this study on Foraminifera N. Solakius received financial support from the Swedish Natural science Research Council G-GU 4746-104, (Anita Löfgren) and from the Project Tornquist (Jan Bergström). For that he wishes to express his gratitude. 
Amedro, F., Bidar, A., Damotte, R., Manivit, H., Robaszynski, F. and Sornay, J., 1978: Échelles biostratigraphiques dans le Turonien du Cap Blanc-Nez (pas-de Calais, F.). Bull Inf. Geol. Bass. Paris, 15 (2), pp. 3-20.

Bailey, H.W. and Hart, M.B., 1979: The Correlation of the Early Senonian in Western Europe using Foraminiferida. Aspekte Kreide Europas, pp. 159-169.

Bailey, H.W., Gale, S.A., Mortimore, R.N., Swiecicki, A. and Wood, Ch.J., 1984: Biostratigraphical criteria for the recognition of the Coniacian to Mastrichtian stage boundaries in the Chalk of north-west Europe, with particular reference to southern England. Bull. Geol. Soc. Denm., $32(1-2)$, pp. 31-39.

Birkelund, T., 1957: Upper Cretaceous Belemnites from Denmark. Biol. Skr. Dan. Vid. Selsk., 9 (1), 69 pp.

Brotzen, F., 1936: Foraminiferen aus dem schwedischen, untersten Senon von Eriksdal in Schonen. Sver. Geol. Unders. Ser. C., 396, 206 pp.

Brotzen, F., 1942: Die Foraminiferengattung Gavelinella nov. gen. und die systematik der Rotalifformes. Sver. Geol. Unders. Ser. C., 451, 60 pp.

Brotzen, F., 1945: De geologiska resultaten frăn borringarna vid Höllviken. Del. I: Kritan. Sver. Geol. Unders. Ser. C, 465, 64 pp.

Butt, A.A., 1966: Foraminifera of the type Turonian. Micropal., 12 (2), pp. 168-182.

Carter, D.J. and Hart, M.B., 1977: Micropaleontological investigations for the site of the Thames Barrier, London. Q.J1 Engng. Geol., 10, pp. 321-338.

Chatziemmanouil, J., 1982: The Upper Cretaceous of the Vomb Trough, southern Sweden. Stockh. Contr. Geol., 38 $(5-6)$, pp. 57-161. 
Christensen, W.K., 1973: The belemnites and their stratigraphical significance. In: Bergström, J., Christensen, W.K., Johansson, C. and Norling, E.: An extension of Upper Cretaceous rocks to the Swedish west coast at Särdal. Bull. Geol. Soc. Denm., 22, 83-154. Christensen, W.K., 1983: The mid to Upper Cretaceous of southern Scandinavia. Cretaceous Stage Boundaries, Abstracts, pp. 32-36.

Christensen, W.K., 1984: The Albian to Maastrichtian of Southern Sweden and Bornholm, Denmark: a Review. Cretaceous Research 5, 313-327.

Cushman, J.A., 1926: Eouvigerina, a new genus from the cretaceous. Cush. Lab. Foram. Res. Contr., pp. 3-6.

Cushman, J.A., 1946: Upper Cretaceous Foraminifera of the Gulf Coastal Region of the United States and adjacent areas. Geol. Surv. Prof. Paper, 206, pp. 1-160. Devries, A., Mathieu., Monciardini, C., Pajaud, D. and Sornay, J., 1974: Données 1ithologiques et biostratigraphiques dans le Turonien et le senonien de la Thiérache et du Marlois (Nord-Est du bassin de Paris). Bull. B.R.G.M. (2), sect. 1, pp. 189-208.

Donze, P., Porthault, B., Thomel, G. and Villoutreys, $0 .$, 1970: Le Senonien inférieur de Puget-Théniers (A1pes-Maritimes) et sa microfaune. Geobios, 3 (2), pp. 41-106.

Douglas, R.G. and Rankin, C., 1969: Cretaceous planktonic Foraminifera from Bornholm and their zoogeographic significance. Lethaia 2, pp. 185-217.

Edwards, P.G., 1981: The foraminiferid genus Gavelinella in the Senonian of north-west Europe. Palaeont., 24, pp. $391-415$.

Ehrenberg, C.G., 1854: Mikrogeologie 374 pp.

Gry, H., 1960: Geology of Bornholm. Intern. Geol. Congr. 21 session. Norden 1960, pp. 1-16.

Hagn, H., 1953: Paläontologishe Untersuchungen am Bohrgut der Bohrungen Ortenburg CF 1001, 1002 und 1003 in Niederbayern. Z . deutsch. geol. Ges., 105, pp. 324-359. 
Hart, M.B., Bailey, H.W., Fletcher, B., Price, R. and Swiecicki, A., 1981: Cretaceous. In Jenkins, D.G. and Murray, J.W. (eds.): Stratigraphic Atlas of Fossil Foraminifera, Ellis Horwood Ldt., Chichester, pp. 149-227.

Hercogova, J., 1977: The Foraminifera: their significance for the stratigraphy of the Cretaceous of Bohemia. Actes VIe Coll. Afr. Micropal. 1, pp. 401-443.

Hercogova, J., 1983: Bohemian Cretaceous Basin. In Klein, V.: 18th Eur. Coll. Micropal., pp. 192-195.

Hiltermann, H. and Koch, W., 1956: Mikropaläontologische Feinhorizontierung von Santon-Profilen durch das Erzlager Lengende-Broistedt. Palaont. Z., 30, pp. 33-44.

Hofker, J., 1957: Foraminiferen der Oberkreide von Nordwestdeutschland und Holland. Geol. Jb., 27, 464 pp.

Koch, W., 1977: Biostratigraphie in der oberkreide und Taxonomie von Foraminiferen. Geol. Jb., 38, pp. $11-123$.

Kuntz, C. and Monciardini, C., 1981: Le Crétacé supérieur des feuilles A $1 / 50.000$ Neufchatel et Beaumont-le Roger (Normandie). Bull. Inf. Geol. Bass. Paris, 18 (4), pp. 53-57.

Marie, P., 1941: Les Foraminiferes de la craie á Belemnitella mucronata du Basin de Paris. Mem. Mus. Nat. Hist. Natur., 12, 296 pp.

Marsson, T., 1878: Die Foraminiferen der weissen Schreibkreide der Insel Rügen. Mitteil. Naturw. Ver. Neuverpommern u. Rügen, 10, pp. 115-196.

Monciardini, C., 1978: Biozones de Foraminifères et faciès du Turonien dans le Nord du bassin de Paris. Bull. B.R.G.M. Sect. 1,3 , pp. 207-223.

Montanaro-Gallitelli, E., 1957: A revision of the family Heterohelicidae. U.S. Nat. Mus. Bull., 215, pp. 133-154.

Norling, E., 1978: Beskrivning till berggrundskartan och flygmagnetiska kartan Kristianstad so. In Kornfält, K-A., Bergström, J., Carserud, L., Henkel, L. and Sundquist, B. Sver. Geol. Unders. Serie Af, 121, 120 pp. 
Orbigny, A.D., $a^{\prime}$., 1840: Memoire sur les Foraminiféres de la Craie Blanche du bassin de Paris. Mem. Soc. Geol. France, 4, pp. 1-51.

Peryt, D., 1980: Planktic Foraminifera zonation of the Upper Cretaceous in the Middle Vistula River Valley, Poland. Paleont. Polon., 41, pp. 1-101.

Pomerol, B., Damotte, R., Fouray, M. and Monciardini, C., 1983: Précisions biostratigraphiques sur la limite Turonien-Sénonien dans la région stratopique de Sens (Yonne). C.R. Acad. Sc. Paris, t. 297, Ser. 2, pp. 421-424.

Pomerol, B. and Monciardini, C., 1983: Le Crétacé supérieur des feuilles A $1 / 50.000$ Estissac et Aix-En-Othe (Limite Sénonais-Champagne). Bull. Inf. Geol. Bass. Paris, 20 (2), pp. 35-44).

Ravn, J.P.J., 1918: Kridtaflejringer paa Bornholms Sydvestkyst og deres Fauna. Turonet. Danm. Geol. Unders., raekke $2,31, \mathrm{pp} .1-37$.

Ravn, J.P.J., 1930: Nogle bemaerkninger om Bornholms kridtaflejringer. Geol. Fören. Förhandl., 52 (2), pp. 279-283.

Reuss, A.E., 1854: Beiträge zur Charakteristik der Kreideschichten in den Ostalpen, besonderes im Gosauthale und am Wolfgangsee. Denkschrift K. Akad. Wiss., 7, $156 \mathrm{pp}$.

Reuss, A.E., 1860: Die Foraminiferen der westphälischen Kreideformation. Sitz. - Ber. Akad. Wiss., math. naturwiss. Cl., 40, pp. 147-238.

Robaszynski, F., 1983: Conclusions to the Colloquium on the Turonian stage: Integrated biostratigraphic charts and facies maps (France and adjacent areas). Zitteliana, 10, pp. 585-594.

Stenestad, E., 1972: Traek af det Danske bassins udvikling $i$ oevre Kridt. Dansk geol. Foren. Åsskrift for 1971, pp. 63-69.

Tollmann, A., 1960: Die Foraminiferenfauna des Oberconiac aus der Gosau des Ausseer Weissenbachtales in Steiermark. Jb. Geol. B.A., 103, pp. 133-203. 
Trumper, E., 1968: Variationsstatistische Untersuchungen an der Foraminiferen-Gattung Stensioeina Brotzen. Geologie, 59, pp. 1-103.

Vasilenko, V.P., 1961: Upper Cretaceous foraminifers of the Mangyshlak Peninsula (descriptions, phylogenetic diagrams of some groups and stratigraphical analysis). Trudy vses. neft. nauchno-issled, geol. razv. Inst., 171, pp. 1-484. (In Russian).

White, M.P., 1928: Some index foraminifera of the Tambico embayment area of Mexico. Part 2. J. Paleont., pp. $280-317$. 
Plate 1

(each bar equal to $100 \mu \mathrm{m}$ )

Figs . 1-2 .

Reussella kelleri Vasilenko

Side and apertural views. LO $5626 t$.

Sample Bm-5.

Figs . 3,9.

Reussella cushmani Brotzen

Side and apertural views. LO $5627 t$.

Sample Bm-5.

Figs. 4-5, 10. Marginotruncana marginata (Reuss)

Spiral, side and umbilical views. LO 5628

t. Sample Bm-7.

Figs . 6-8.

Gavelinella stelligera (Marie)

spiral, side and umbilical views.

LO 5629 t. Sample Bm-5.

Figs. 11-13

Gavelinella thalmanni (Brotzen)

Spiral, side and umbilical views.

LO 5630 t. Sample Bm-7.

Figs. 14-25, 20. Globotruncana renzi Gandolfi

Spiral, side and umbilical views.

LO 5631 t. Sample Bm-5.

Figs . 16-18.

Stensioeina exsculpta exsculpta (Reuss)

Spiral, side and umbilical views.

LO 5632 t. Sample Bm-ll.

Figs. 19, 23-24. Spiral, side and umbilical views of a specimen belonging to the Dicarinella cf. concavata (Brotzen). LO 5633 t.

Sample Hs-2.

Figs. $21-22$.

Cibicides excavata Brotzen

Apertural and spiral views. Lo $5634 t$. Sample Hs-2. 


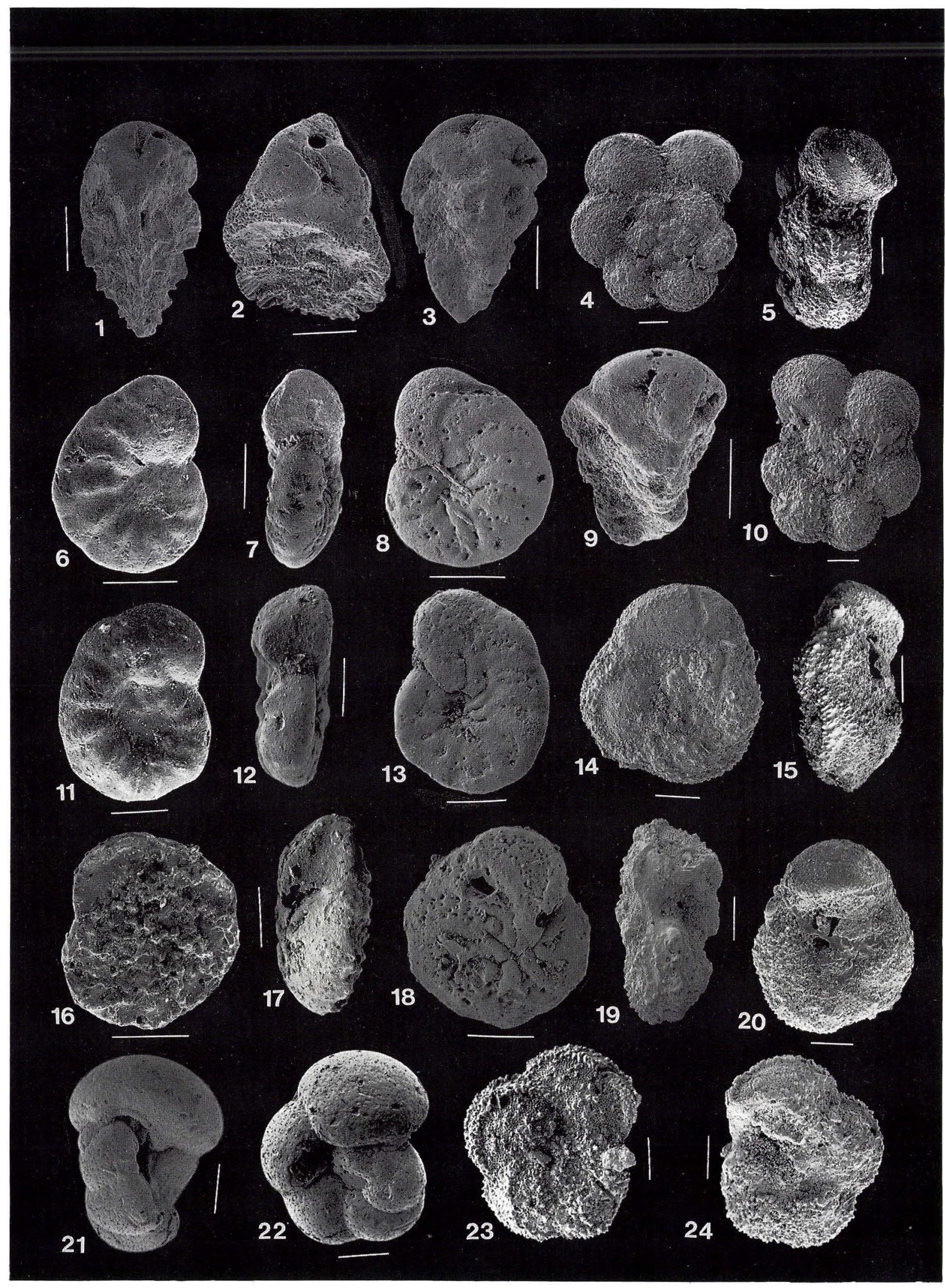




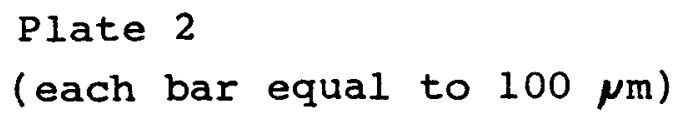

Fig. 3 .

Figs . 4-5
Gavelinella thalmanni (Brotzen)

Spiral side. LO 5637 t. Samle Bm-7.

Stensioeina exsculpta exsculpta (Reuss)

Spiral and umbilical views of the specimen illustrated by Brotzen (1936) in pl. 11, Fig. 8, Eriksdal, Skåne. Pr. 155. Swedish Museum of Natural History, Stockholm.

Figs. 6, 12-13. Gavelinopsis tourainensis Butt spiral, umbilical and side views of a specimen from the type sample, Turonian, France. LO 5638 t.

Figs . 8-10 Stensioeina exsculpta exsculpta (Reuss) spiral, side and umbilical views. LO 5639 t. Sample Hs-5.

Figs. 11, 16-17. Marginotruncana cf. paraconcavata Porthault

Side, umbilical and spiral views. LO 5640 t. Sample Bm-7.

Figs . 14-15 Osangularia whitei (Brotzen)

Umbilical and spiral views of a specimen from the type sample IIb, Eriksdal, Skåne. Pr. 1687. Brotzen's collection, Swedish Museum of Natural History. Figs. 18-20. Dicarinella concavata (Brotzen) Spiral, side and umbilical views. Pont du Fachs, Tunisia. LO 5641 t. Figs. 21-23. Neoflabellina suturalis suturalis (Cushman)

LO 5642 t. Sample Hs-5.

Fig. 24 .
Verneuilina muensteri Reuss Apertural view. LO 5670 t. Sample Bm-7. 


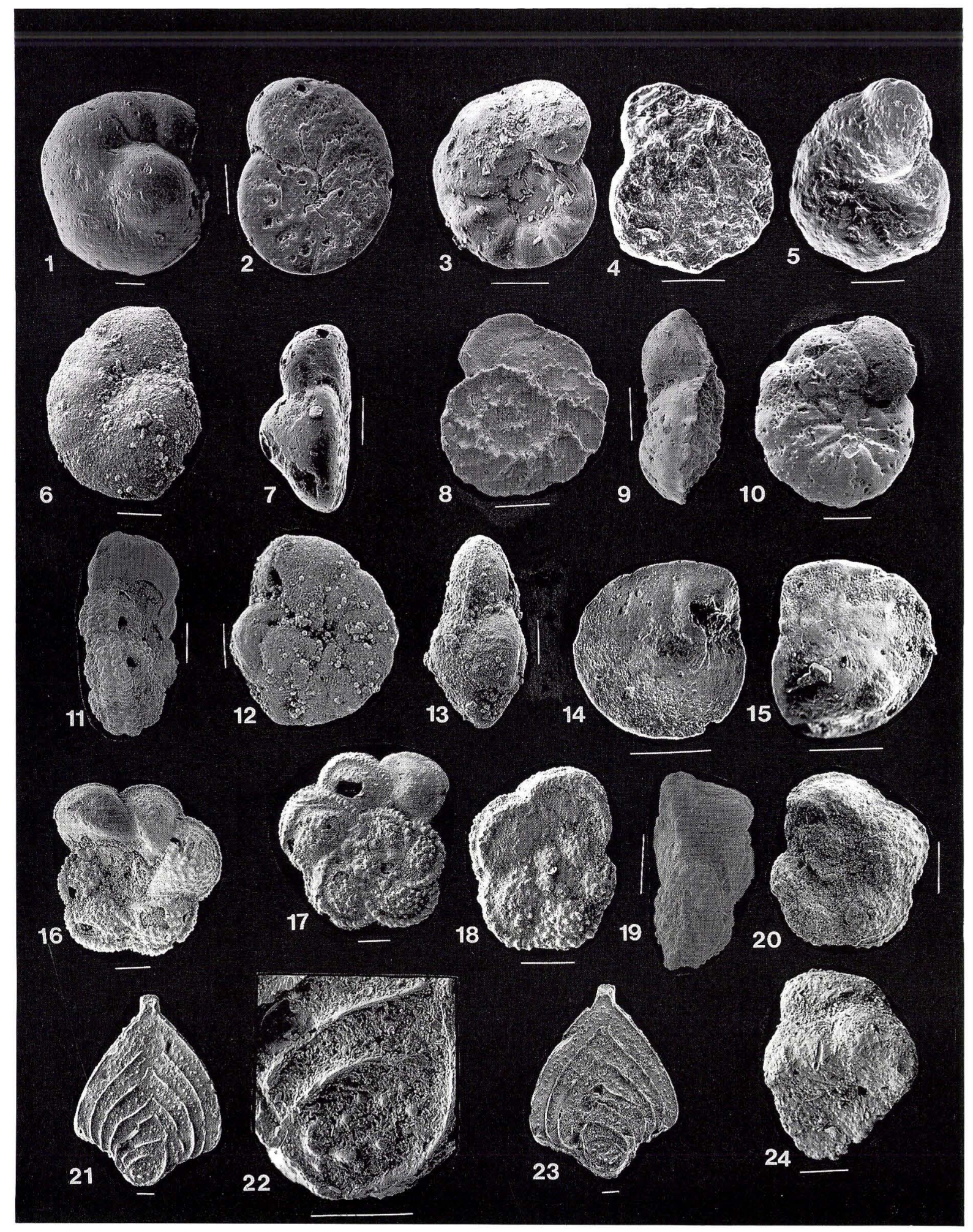


Figs. 1-3

Figs. 4, 8 .

Fig. 5 .

Figs. 6-7, 12 .

Fig. 9 .

Figs . 10-11.

Fig. 13 .

Figs. 14-16.

Figs. 17-19.
Gavelinella pertusa (Marsson)

Spiral, side and umbilical views.

LO 5671 t. Sample Bm-9.

Gaudryina rugosa d'orbigny

Side and apertural view.

LO 5672 t. Sample Bm-12.

Vaginulinopsis scalariformis Porthault $\overline{\text { Side view. LO }} 5 \overline{673 \text { t. Sample }} \mathrm{Bm}-7$.

Cibicides ribbingi Brotzen

Spiral, side and umbilical views.

Eriksdal, Skåne. Brotzen's collection,

Pr. 104. Swedish Museum of Natural

History.

Loxostomum eleyi (Cushman)

Side view. LO 5675 t. Sample Hs-4.

Cibicides ribbingi Brotzen

Side and umbilical views.

LO 5676 t. Sample Hs-4.

Eouvigerina aculeata (Ehrenberg)

Side view. LO 5674 t. Sample Bm-7.

Marginotruncana cf. angusticarinata

(Gandolfi)

Spiral, side and umbilical views.

LO 5677 t. Sample Bm-12.

Osangularia whitei (Brotzen)

17. Spiral view. Lo 5678 t.

18-19. Side and umbilical views.

LO 5679 t. Sample Bm-7. 


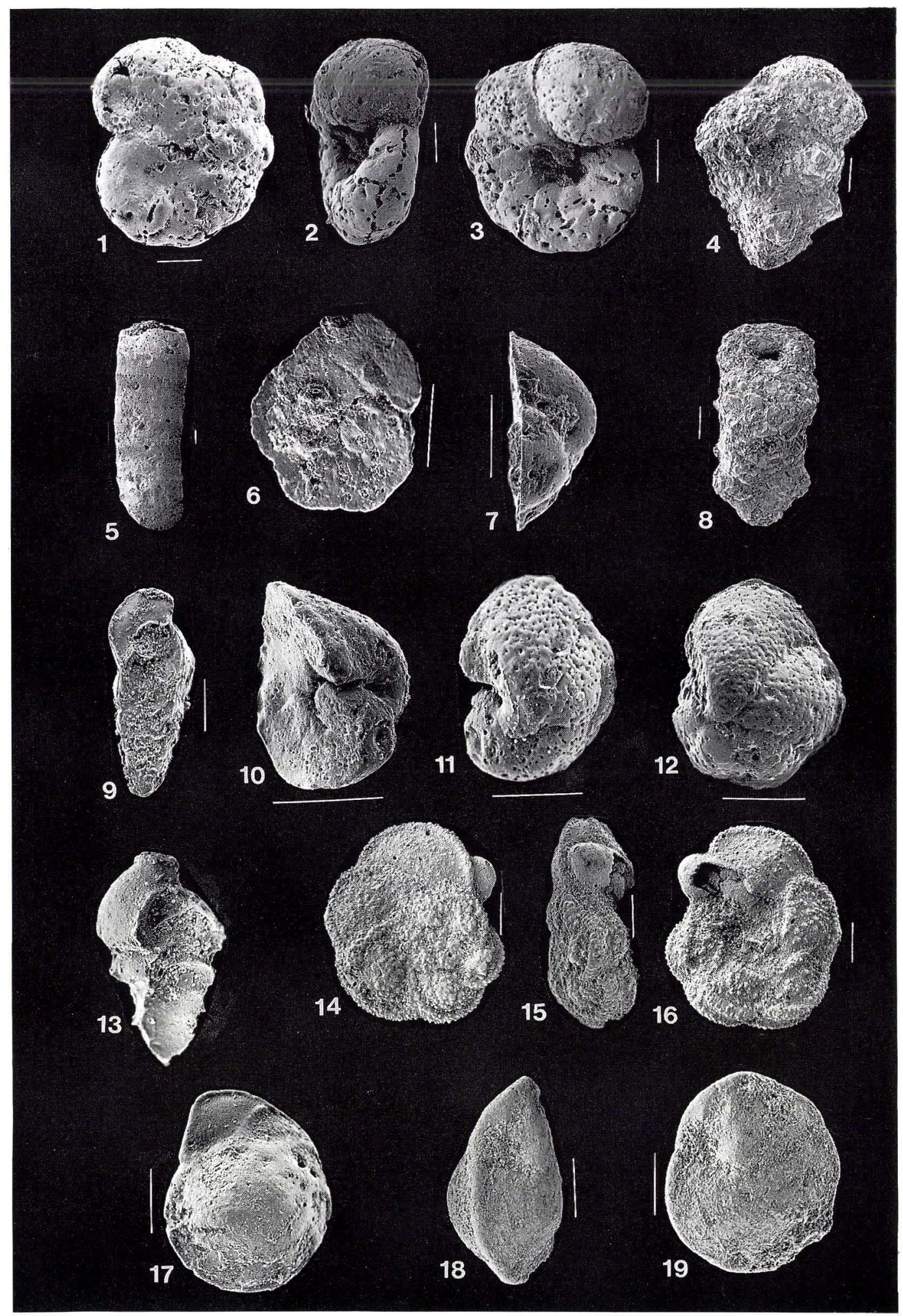


Foraminifera from the Arnager Limestone, Bornholm, have been recorded and identified. The fauna examined indicated a Conacian age for the Arnager Limestone. On the basis of this fauna two benthonic foraminiferal zones, the Reussella kelleri Zone and the Stensioeina exsculpta Zone, are recognized in the limestone. Apart from the index species only the biostratigrapically most significant species are discussed.

Geological Survey of Denmark

Thoravej 31

DK 2400 Copenhagen NV

Denmark 